\title{
Determining Students’ Attitudes Toward Ecological Phenomena in Learning Environmental Physics Subject
}

\author{
N. D. Napitupulu \\ Department of Physics Education \\ Universitas Tadulako \\ Palu, Indonesia \\ nurdewi66@yahoo.com
}

\author{
A. Munandar, S. Redjeki, B.Tjasyono \\ Department of Science Education \\ Post Graduate, Universitas Pendidikan Indonesia \\ Bandung, Indonesia
}

\begin{abstract}
Learning about the environment become prominent in dealing with natural phenomena that occur nowadays. Studying environmental physics will lead students to have a desire noticed on particular phenomenon or ecological issues (receiving), participating actively as part of behavior (responding), involves determining the value of attitude or commitment (valuing), classify between positive attitude and negative attitude, and action collaboratively, and has a character who care about the environment (creating or characterizing). This research aimed at describing the attitude toward ecological issues. A validated questionnaire was given to 37 students who already programmed the environmental physics, as an elective course at physics education department to see the student's attitudes competence toward ecological phenomena. By the qualitative research approach, the research shows the percentage positive attitudes less than the negative attitudes.The results obtained at the interview give guidance to suppose that this result was due to the teaching model at the environmental physics course.
\end{abstract} physics

Keywords-attitude; ecological phenomena; environmental

\section{INTRODUCTION}

The effective competence is one of the three competencies as outcome learning set by the Indonesian government as a standard of higher education that refers to the Indonesian National Qualification Framework (KKNI) to encourage the realization of character through learning [1].The effective competency refers to behaviors that emphasize aspects of feelings and emotions, such as interests, attitudes, appreciations, and ways of adjustment. In other words, effective competence is an attitude (attitude), behavior (behavior), and action (action) are interconnected and integrated [2], [3]. Blooms' taxonomy describes an effective taxonomy in five accessible categories: receiving, responding, valuing, organizing, and creating/characterizing. The receiving category indicates the desire to know and care; The responding category indicates a response to active participation as part of its behavior; Valuing involves determining values, beliefs or attitudes and commitments; Organizing refers to the ability to organize attitudes and engage in joint actions; And creating/ characterizing is an attitude and commitment; Organizing refers to the ability to organize attitudes and engage in joint actions; and creating/characterizing is an attitude that is formed into characters [3]. These five categories are actually the level or level of attitude formation process from the lowest level (receiving) to the highest level (creating/characterizing). This character is an attitude of high commitment because it is formed from a series of thoughts (cognitive), effective, and behaviors that become a habit [4].

When the attitude is understood as a behavior or an evaluation of nature, this means that attitudes are determined by the person's beliefs about the object of attitude, whether positive or negative, which is described as a link to the totality of his affection with his beliefs [5]. In other words, beliefs influence one's attitude and behavior so that it acts in a certain way.

Attitudes can be established through various models or learning methods that encourage student activeness, such as inquiry-based learning, problem-based learning, project-based learning. The results show that inquiry-based eco-pedagogy improves student attitudes in the environmental physics lectures, especially on ecological issues they know. Similarly, based learning projects can improve attitudes in physics lectures conducted in the laboratory, and even problem-based learning can improve attitudes and the ability to think critically [6]-[8]. Thus, attitudes can be formed and developed through appropriate learning through various models and approaches.

Ecological attitude is one of the outcomes in the environmental physics lecture because environmental physics as part of science is related to the understanding of the natural environment [9], [10], where the principles of physics are applied to understanding environmental problems. The existence of environmental issues as ecological phenomena toward local and global issues, such as climate change, deforestation, and the use of energy resources that are part of the learning of physics, encourage the involvement of all fields to take a position, including the world of education. Therefore, physics education should provide insight into the values of ecological awareness and concern for its ecological phenomena as the actualization of attitudes to a harmonious and sustainable life [11]. Based on the background, the aim of the research is to 
determine the positive attitude and the negative attitude of Physics Education students after passed two semesters of Environmental Physics course.

\section{METHOD}

The method used in this research surveyed by descriptive qualitative research approach which determined the percentage of positive and negative attitudes toward ecological phenomena. The respondents of this research were Physics Education students after two semesters passed that Environmental Physics course at Universitas Tadulako Palu, Sulawesi Tengah. The instrument for collecting data used a validated questionnaire given to 37 students.

The attitudes ecological phenomena instrument include 150 questions that represent ecological issues trends in Sulawesi Tengah as shown in Tabel I. The attitudes categories consists of receiving, responding, valuing, organizing, and creating/characterizing. As for categorization attitudes refers to the Blooms' affective taxonomy [3] as shown in Table II.The attitudes ecological questionnaire forms in favorable and unfavorable statements with two alternative answers as YES, and to find out the positive attitude and negative attitude of the respondents, two choices YES or NO, as shown in Table II, were given.

\section{TABLE I. THE ATTITUDES ECOLOGICAL INSTRUMENT}

\begin{tabular}{|c|c|c|c|c|c|c|}
\hline \multirow{2}{*}{$\begin{array}{c}\text { Ecological } \\
\text { Phenomena }\end{array}$} & \multirow[t]{2}{*}{ Subjects } & \multicolumn{5}{|c|}{ Items of Attitudes } \\
\hline & & 1 & 2 & 3 & 4 & 5 \\
\hline \multirow[t]{3}{*}{$\begin{array}{l}\text { Climate } \\
\text { Change }\end{array}$} & $\begin{array}{l}\text { Global warming and } \\
\text { greenhouse effect }\end{array}$ & \multirow[t]{3}{*}{9} & \multirow[t]{3}{*}{9} & \multirow[t]{3}{*}{9} & \multirow[t]{3}{*}{9} & \multirow[t]{3}{*}{9} \\
\hline & Extreme Environment & & & & & \\
\hline & $\begin{array}{l}\text { Mitigation urgency climate } \\
\text { change }\end{array}$ & & & & & \\
\hline \multirow[t]{4}{*}{ Deforestation } & Damage to lithosphere & \multirow{4}{*}{$\begin{array}{l}1 \\
2\end{array}$} & \multirow{4}{*}{$\begin{array}{l}1 \\
2\end{array}$} & \multirow{4}{*}{$\begin{array}{l}1 \\
2\end{array}$} & \multirow{4}{*}{$\begin{array}{l}1 \\
2\end{array}$} & \multirow{4}{*}{$\begin{array}{l}1 \\
2\end{array}$} \\
\hline & Damage to hydrosphere & & & & & \\
\hline & Damage to ecosystems & & & & & \\
\hline & $\begin{array}{ll}\begin{array}{l}\text { Mitigation } \\
\text { deforestation }\end{array} & \text { urgency } \\
\end{array}$ & & & & & \\
\hline \multirow{3}{*}{$\begin{array}{l}\text { Using } \\
\text { Energy } \\
\text { Resources }\end{array}$} & Environmental pollution & \multirow{3}{*}{9} & \multirow{3}{*}{9} & \multirow{3}{*}{9} & \multirow{3}{*}{9} & \multirow{3}{*}{9} \\
\hline & Electrical energy crisis & & & & & \\
\hline & $\begin{array}{ll}\begin{array}{l}\text { Green alternative energy } \\
\text { urgency }\end{array} & \\
\end{array}$ & & & & & \\
\hline & Sum & 30 & 30 & 30 & 30 & 30 \\
\hline
\end{tabular}

TABLE II. THE EXAMPLES OF STATEMENTS ECOLOGICAL INSTRUMENT

\begin{tabular}{|c|c|c|c|c|}
\hline \multirow{2}{*}{$\begin{array}{c}\text { No } \\
\text {. }\end{array}$} & \multirow{2}{*}{$\begin{array}{c}\text { Attitudes } \\
\text { Categories }\end{array}$} & \multirow[t]{2}{*}{ Statement Attitudes } & \multicolumn{2}{|c|}{ Answers } \\
\hline & & & $Y E S$ & $N O$ \\
\hline 14 & Receiving & $\begin{array}{l}\text { I do not care that the source of } \\
\text { drinking water in Palu contains } \\
\text { Mercuri due to gold mining in Poboya }\end{array}$ & & \\
\hline 37 & Responding & $\begin{array}{l}\text { I have not prepared anything to face } \\
\text { the extreme weather nowadays }\end{array}$ & & \\
\hline 61 & Valuing & $\begin{array}{l}\text { I am convinced that climate change in } \\
\text { Palu does not impact climate change } \\
\text { in other countries }\end{array}$ & & \\
\hline $\begin{array}{c}10 \\
2\end{array}$ & Organizing & $\begin{array}{l}\text { I support the government's efforts to } \\
\text { prohibit the Poboya gold mine that } \\
\text { caused soil damage }\end{array}$ & & \\
\hline $\begin{array}{c}15 \\
0\end{array}$ & Creating & $\begin{array}{l}\text { Under no circumstances, I do not turn } \\
\text { off my mobile phone every time I } \\
\text { want to sleep. }\end{array}$ & & \\
\hline
\end{tabular}

\section{RESULT AND DISCUSSION}

Based on the research that had been conducted on 37 Physics Education students, the positive and negative attitudes percentage showed in Table III. The percentage means for the positive attitudes was 47.55 , and the negative attitudes were 52.45. For the attitudes categories, the percentage of positive and negative attitudes for each aspect was 78.73 and 22.27 (receiving), 45.74 and 54.26 (responding), 41.64 and 58.36 (valuing), 31.26 and 68.74 (organizing), and 40.39 and 59.61 (creating/characterizing).

\section{TABLE III THE PERCENTAGE OF THE ATTITUDES ON EACH} CATEGORY

\begin{tabular}{|l|c|c|}
\hline \multirow{2}{*}{$\begin{array}{c}\text { Attitudes } \\
\text { Categories }\end{array}$} & \multicolumn{2}{|c|}{ Attitudes Percentage } \\
\cline { 2 - 3 } & Positive & Negative \\
\hline Receiving & 78.73 & 21.27 \\
Responding & 45.74 & 54.26 \\
Valuing & 41.64 & 58.36 \\
Organizing & 31.26 & 68.74 \\
Creating & 40.39 & 59.61 \\
\hline \multicolumn{1}{|c|}{ Means } & 47.55 & 52.45 \\
\hline
\end{tabular}

Based on Table III, the percentage means of positive attitudes less than negative attitudes. This shows that the Environmental Physics course did not develop the students' attitudes toward ecological phenomena although they have passed two semesters. This finding is a contrast to the understanding that learning is an important thing that should be done in order to respond every challenge on the current situation and the future. The outcome or competency of learning can be achieved through learning that change of behavior through real experiences [12].

The percentage of attitudes by category is shown in Fig. 1. According to the table, from five categories of attitudes found that the receiving category has a greater positive attitude than the negative attitude. This is different from the other four categories of attitudes in which a negative attitude is greater than a positive attitude.

\section{Attitudes Percentage}

C

a

$\mathrm{t}$

e

g $\mathrm{s}$

0

r

i

e

Fig. 1 The percentage of students' positive and negative attitudes

Fig. 1 shows that the result of Environmental Physics learning in the formation of ecological attitude is the attitude of 
receiving only. In Affective Bloom taxonomy [3], receiving category is the lowest category where the learners are curious and know only, have not taken any action. This is reinforced by attitudes in the other four categories (responding, valuing, organizing, and creating/characterizing) that exhibit a greater negative attitude than a positive attitude.

The results showed that the learning model is very influential on the formation of attitude[6]-[8], [13]. Based on student interviews, it was found that learning was done by assignment only, where each group was assigned to the results of the discussion will be presented in accordance with a predetermined schedule. This information let us know that lectures are done without associated or corresponding learning model so that students did not get the learning achievement in affective domain after two semesters passes the lecture, the student is in acceptance only. The learning model is one aspect of learning to achieve success defined as learning achievement. Achievement of learning is inseparable from the ability of teachers to develop effective learning models in the learning process where students are actively involved in learning [12].

Description of the percentage of attitudes based on ecological phenomena in each attitude category is shown in Table IV.

TABLE IV PERCENTAGE OF ATTITUDES ON EACH ECOLOGICAL PHENOMENA

\begin{tabular}{|l|l|c|c|c|}
\hline Categories & Percentage & $\begin{array}{c}\text { Climate } \\
\text { Change }\end{array}$ & $\begin{array}{c}\text { Deforesta- } \\
\text { tion }\end{array}$ & $\begin{array}{c}\text { Using } \\
\text { Energy } \\
\text { Resources }\end{array}$ \\
\hline Receiving & Positive & 78.98 & 82.43 & 74.77 \\
\cline { 2 - 5 } & Negative & 21.02 & 17.57 & 25.23 \\
\hline Responding & Positive & 45.34 & 54.05 & 37.83 \\
\cline { 2 - 5 } & Negative & 54.66 & 45.95 & 62.17 \\
\hline Valuing & Positive & 45.64 & 31.53 & 47.74 \\
\cline { 2 - 5 } & Negative & 54.36 & 68.47 & 52.26 \\
\hline Organizing & Positive & 32.13 & 21.40 & 40.24 \\
\hline \multirow{2}{*}{ Creating } & Negative & 67.87 & 78.60 & 59.76 \\
& Positive & 46.84 & 34.68 & 39.64 \\
\cline { 2 - 5 } & Negative & 53.16 & 65.32 & 60.36 \\
\hline
\end{tabular}

As can be seen in Table IV, it is shown that the receiving attitude category, the largest percentage of positive attitudes is the ecological phenomenon of deforestation $(82.43 \%)$ while the percentage of the biggest negative attitude toward the use of resources $(24.23 \%)$. In the category of responding, although the negative attitude is higher than the positive attitude, the phenomenon of deforestation is the positive attitude $(54.05 \%)$ greater than the negative attitude $(45.95 \%)$, and the biggest negative attitude toward the use of resources $(62.17 \%)$. This situation is in contrast to the category of attitudes of valuing, organizing, and creating which in the deforestation phenomenon the percentage of the biggest negative attitudes, respectively $68.47 \%, 78.60 \%$, and $65.32 \%$, while the positive attitudes of the three categories are below $50 \%$. The percentage comparison chart of this attitude is shown in Fig. 2.

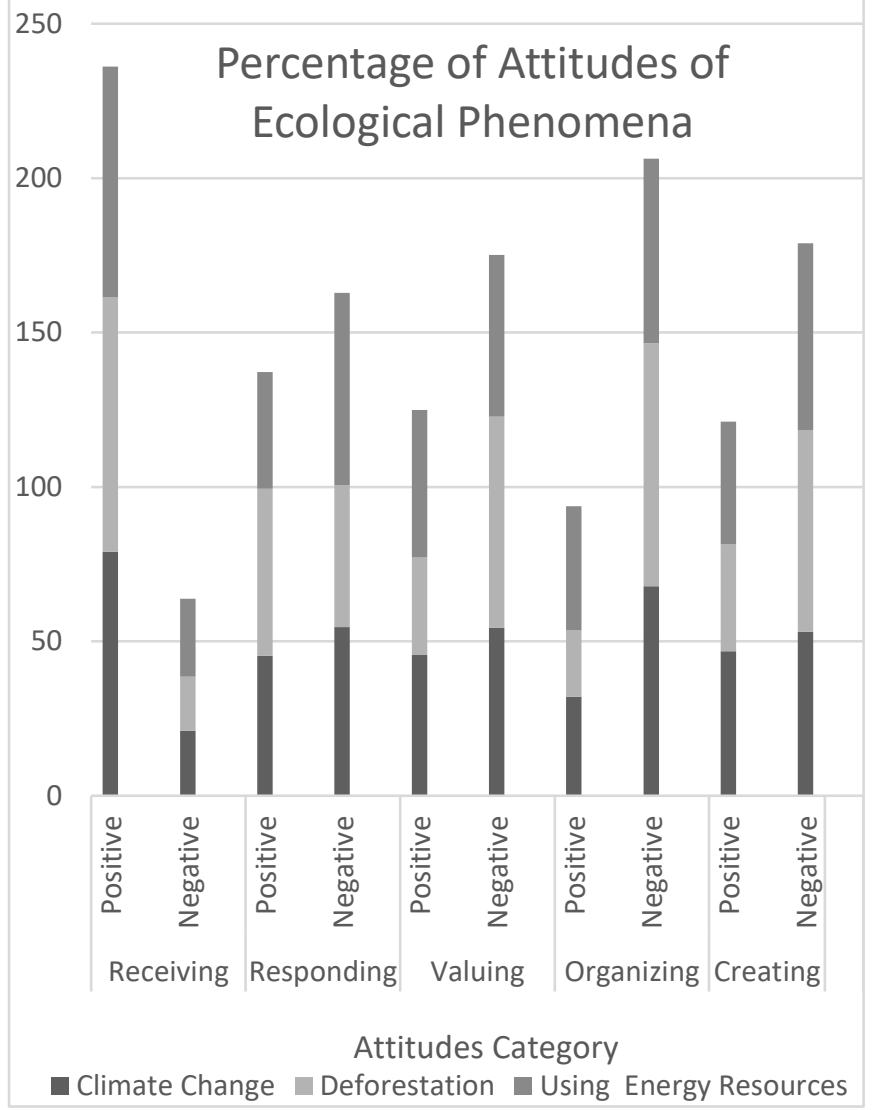

Fig. 2. Comparison diagram of percentage of positive and negative attitudes on each ecological phenomena

The recent escalating deforestation phenomenon in Central Sulawesi is a real phenomenon in communities where communities are involved as agents of deforestation through clearing forests into agricultural land and housing. Meanwhile, the biggest negative attitude to the responding category is to the use of energy resources; category of valuing against deforestation; the organizing category of deforestation; and category creating/characterizing against deforestation. This negative attitude is evidenced by the escalation of lithosphere and hydrosphere damage due to gold mining in Poboya, and damage to forest ecosystems in Central Sulawesi [14], [15]. Similarly, increased air pollution due to increased use of motorcycle transportation and the occurrence of an electrical energy crisis in Central Sulawesi. This environmental damage becomes an ecological disaster [16] to be addressed, either through the management of conservation areas of physics education and other science education. Mitigation of the electrical energy crisis has been pursued by various alternative energy sources, such as the utilization of solar energy, wind energy, water energy and even energy sources from wave power and air temperature differences [17]. The study of environmental physics with problem-solving is expected to build student awareness and attitude toward environ issues and 
participate in minimizing various local and global ecological phenomena.

\section{CONCLUSIONS}

Based on the result of the description of attitude and discussion above it can be concluded that physics education student's attitude toward ecological phenomena generally has a negative attitude. The positive attitude level is only in the receiving category. The student's biggest negative attitude includes the phenomenon of deforestation which is their attitude on to the environment around the students. It takes the effort of physics education in growing awareness of students to the local environment through learning with various models and learning approaches. Therefore, the environment physics lecture can use the learning model that can build the positive attitude of the students from the category of responding to the category of creating/characterizing, so that mitigation can be done to the ecological problems for a sustainable living. This would be the future work of this study.

\section{ACKNOWLEDGMENT}

The author would like to thank you for Physics Educations students class of 2014 who had been respondents in this study, and especially theRectorof Universitas Tadulako and who support this research.

\section{REFERENCES}

[1] Kemendikbud, "Peraturan Menteri Pendidikan dan Kebudayaan Nomor 49 Tahun 2014 Tentang Standar Nasional Pendidikan Tinggi (SNPT), unpublished.

[2] J. Li, D. Mizerski, A. Lee, and F. Liu, "The relationship between attitude and behavior: an empirical study in China," Asia Pacific J. Mark., 2009.

[3] Anderson and Krathwohl, "Bloom's Taxonomy Revised - The Second Principle." [Online]. Available: http://thesecondprinciple.com/teachingessentials/beyond-bloom-cognitive-taxonomy-revised/. [Accessed: 07Sep-2017].
[4] T. Lickona, Educating for character: How our schools can teach respect and responsibility. 2009.

[5] J. Osborne, S. Simon, and S. Collins, "Attitudes towards science: A review of the literature and its implications," Int. J. Sci., 2003.

[6] A. Masek and S. Yamin, "The effect of problem-based learning on critical thinking ability: a theoretical and empirical review," Int. Rev. Soc. Sci., 2011.

[7] N. D. Napitupulu and A. Munandar, “"Describing The Impact InquiryBased Ecopedagogy on Pre-service Physics Teachers' Achievement and Attitudes,' Proceeding Internasional Seminar on Mathematics, Science, and Computer Science Education. Universitas Pendidikan Indonesia Bandung, pp. 397-402.

[8] S. Liu, "Implementing Project-Based Learning in Physics and Statics Courses," Annu. Conf. Expo. 15-18, 2014), 2014.

[9] J. L. (John L. Monteith, Principles of environmental physics. Academic Press, 2013.

[10] W. P. Cunningham and M. A. Cunningham, Environmental science : a global concern.

[11] Unesco, "Education for Sustainable Development Country," 2011.

[12] R. Arends, "Learning To Teach. Oxford: McGraw-Hill Humanities/Social science/languages, 2008.

[13] M. Sahin, "of problem-based learning on university students' epistemological beliefs about physics and physics learning and conceptual understanding of Newtonian mechanics," J. Sci. Educ. Technol., 2010.

[14] A. Irawan, "Hubungan iklim mikro dan bahan organik tanah dengan Emisi CO2 dari permukaan tanah,” 2009.

[15] S. Purnawan and R. Sikanna, "Distribusi Logam Merkuri Pada Sedimen Laut Di Sekitar Muara Sungai Poboya," Nat. Sci. J., 2013.

[16] Bahagia SP, "Bahagia SP, 'Bencana dan kerusakan lingkungan,' in Suara Karya, Kolom 2-5, p. 4, 24 Juni 2016. - Google Search,” Suara Karya, 2016.

[17] A. Sam and D. Patabang, "Studi Potensi Energi Angin Di Kota Palu Untuk Membangkitkan Energi Listrik," SMARTek, vol. 3, no. 1, pp. 21-26, 2012. 